\title{
Constraints Expressed by Tribal Women in Farm and Home Management
}

\author{
T.N. Sujeetha*, N. Suganthi and V. Ravichandran \\ Department of Agricultural Extension and Rural Sociology, Tamil Nadu Agricultural University, \\ Coimbatore-641003, Tamil Nadu, India \\ *Corresponding author
}

\section{A B S T R A C T}

\begin{tabular}{|l|}
\hline Ke y w o r d s \\
Constraints, Tribal \\
Women, Role \\
Performance. \\
\hline Article Info \\
\hline $\begin{array}{l}\text { Accepted: } \\
\text { 04 July } 2017 \\
\text { Available Online: } \\
\text { 10 September } 2017\end{array}$ \\
\hline
\end{tabular}

The tribal women expressed a variety of constraints as a result of their role performance in farm and home activities. Among the problems faced, weak extension service in remote places was the primary constraint felt by majority (97.78\%) of the tribal women. The next important problem expressed by the tribal women was the inaccessibility of officials in time. Upon observation, it could be seen that the respondents were highly dissatisfied about the inadequate technical support received from extension officials.

\section{Introduction}

The status of women in a society is a significant reflection of the level of social justice in that society. Women's status is often described in terms of their level of income, employment, education, health and fertility as well as their roles within the family, the community and society. In tribal communities, the role of women is substantial and crucial (Das, 2012). They constitute about half the total population but in tribal society women are more important than in other social groups, because they work harder and the family economy and management depends on them. Even after industrialization and the resultant commercialization swamped the tribal economy, women continued to play a significant role. Collection of minor forest produce is done mostly by women and children. Many also work as laborers in industries, households and construction, contributing to their family income. Despite exploitation by contractors and managers, tribals are more sincere and honest than nontribals (Fabiyi et al., 2007).

\section{Materials and Methods}

Nilgiris district of Tamil Nadu was purposively selected because it is one of the districts in Tamil Nadu in which more percentage of tribal population has been reported. Kotagiri and Udhagamandalam blocks were purposively selected because these two blocks have relatively more percentage of the selected tribal communities viz., Todas, Irulas and Kotas. Of these, four 
revenue villages from Kotagiri block and to revenue villages from Udhagamandalam block were further selected considering the maximum number of identified tribal habitations viz., Todas, Irulas and Kotas.

A sample of 60 tribal women from each tribal community has selected. Random sampling was adopted in selection of the respondents. The total sample size is 180 .

\section{Results and Discussion}

The constraints encountered by the tribal women in their role performance in farm and home management have been collected and presented in the subsequent tables. The following were the constraints encountered and reported to the researcher by the tribal women during the group visits and survey. The results have been displayed in table 1 .

\section{Constraints expressed by tribal women in farm and home management}

The constraints encountered by the tribal women in their role performance in farm and home management have been collected and presented in the subsequent tables. The following were the constraints encountered and reported to the researcher by the tribal women during the group visits and survey. The results have been displayed in table 1 .

It is observed from table 1, that the tribal women expressed a variety of constraints as a result of their role performance in farm and home activities.

Among the problems faced, weak extension service in remote places was the primary constraint felt by majority $(97.78 \%)$ of the tribal women. The next important problem expressed by the tribal women was the inaccessibility of officials in time. Upon observation, it could be seen that the respondents were highly dissatisfied about the inadequate technical support received from extension officials.

The other constraints which were encountered and expressed by the tribal women were the distribution of tree seedlings, fertilizers and pesticides were accessed by the same client. Nearly 89.44 per cent of the respondents experienced that the response from the officials was less. Nearly three fourth $(85.56 \%)$ of the tribal women expressed that the non-availability of adequate inputs in time was also one of the major constraint.

Majority (91.67\%) of the respondents had mentioned that the subsidies available in the programmes were less and they need more number of subsidies in agriculture and allied sectors. The other constraint reported was insufficient credit facilities where majority $(89.44 \%)$ of the tribal women could not get credit for the agricultural purpose at the right time and it is suggested that the formalities in sanctioning the credit may be simplified. This will minimize their dependency on money lenders for credit. The other major constraint that the tribal women faced was difficulty in loan repayment, as reported by 79.44 per cent of them. Due to their low economic status, they are not able to repay the loans available from the nationalized banks and co-operative societies.

Among the personal problems faced, more prevalence of social taboos, superstitions and traditions (64.34\%), indebtedness $(51.11 \%)$, and more fear of social security, domestic violence and abusive behavior (47.78\%) were the major constraints reported by the tribal women. A few observations made during the data collection revealed that the tribal communities habitually run into debts and more so when adverse seasonal conditions prevail. The problem of indebtedness among the tribal community is a major cause of their 
exploitation. The tribal women are so much in dept. to money-lender that he may stake their own life and the life of the family in their service for a long period of time.

Table.1 Constraints expressed by tribal women in farm and home management $(n=180)$

\begin{tabular}{|c|l|c|c|c|}
\hline \multirow{2}{*}{ No. Constraints } & \multicolumn{1}{|c|}{ Total (n=180)* } & Rank \\
\cline { 3 - 4 } & & No & \% & \\
\hline a. & Extension constraints & & & \\
\hline 1. & Non availability of adequate inputs in time & 154 & 85.56 & IV \\
\hline 2. & Lack of response from officials & 161 & 89.44 & III \\
\hline 3. & Inadequate technical support from officials & 133 & 73.89 & VII \\
\hline 4. & Weak extension service in remote places & 176 & 97.78 & I \\
\hline 5. & Inaccessibility of officials & 170 & 94.34 & II \\
\hline 6. & Lack of adequate training facilities & 150 & 83.33 & V \\
\hline 7. & More administrative formalities & 143 & 79.44 & VI \\
\hline b. & Economic constraints & & & \\
\hline 1. & Difficulty in loan repayment & 143 & 79.44 & IV \\
\hline 2. & Insufficient credit facilities & 161 & 89.44 & II \\
\hline 3. & Subsidies available in programmes are less & 165 & 91.67 & I \\
\hline 4. & Non availability of timely credit & 157 & 87.22 & III \\
\hline c. & Personal constraints & & & \\
\hline 1. & Lack of self-motivation & 73 & 40.56 & IV \\
\hline 2. & Illiteracy & 48 & 26.67 & VI \\
\hline 3. & More social taboos, superstitions and traditions & 116 & 64.34 & I \\
\hline 4. & Indebtedness & 92 & 51.11 & II \\
\hline 5. & More fear of social security, domestic violence & 86 & 47.78 & III \\
\hline 6. & and abusive behavior & & & V \\
\hline d. & Suppression due to the dependable nature of & 68 & 37.78 & V \\
\hline 1. & Non-availability of hospital facilities & 118 & 65.56 & III \\
\hline 2. & Lack of well-constructed houses & & 82.22 & II \\
\hline 3. & Lack of marketing facilities & $\mathbf{7 2 . 6 4}$ & \\
\hline & Overall mean score & & & \\
\hline
\end{tabular}

* Multiple responses

Non-availability of proper medical facilities to the tribal areas was reported by 85.00 per cent of the respondents. The reasons are inadequate medical aid for the tribes who live in isolated villages and the facilities available in the main place were not sufficient. More than half of the respondents $(82.22 \%)$ reported that they suffered from lack of marketing facilities and due to this problem, their agricultural produce was exploited by the middle men. The other major problem that the tribal women stated was lack of wellconstructed houses. Nearly 65.56 per cent of the tribal women blamed the government for not accomplishing what they had actually promised that they will do these downtrodden tribal communities.

The constraints expressed by the tribal women may have to be considered especially in aspects like weak extension service in remote places, the inaccessibility of officials 
in time, inadequate technical support received from extension officials and distribution of tree seedlings, fertilizers and pesticides were accessed by the same client. According to Singh (2013), the government should focus empowerment of schedule tribe women and allocate separate Funds throughout the five years plan. Health, education and nourishment should be selected Key focus areas, besides; women should be provided ample opportunities for economic development, based upon the traditional skills, women should also be provided additional skills for value additions to the produces. If the constraints are properly addressed, then the tribal women for no doubt will be into the limelight on par with the non tribals.

\section{References}

Das, S., 2012. An Analysis of Constraints in Women Empowerment in Tribal Area: Evidences from Assam. Asian Journal of Research in Social Science and Humanities, 3:56-74.

Fabiyi, E. F., B. B. Danladi, K. E. Akande and Y. Mahmood. 2007. Role of Women in Agriculture Development and their Constraints: A Case Study of Biliri Local Government Area, Gombe State, Nigeria. Pakistan Journal of Nutrition, 6:676-680.

Singh, S., 2013. Women Empowerment in Modern India, from http://ssrn.com/abstract=2361581

\section{How to cite this article:}

Sujeetha, T.N., N. Suganthi and Ravichandran, V. 2017. Constraints Expressed by Tribal Women in Farm and Home Management. Int.J.Curr.Microbiol.App.Sci. 6(9): 536-539. doi: https://doi.org/10.20546/ijcmas.2017.609.064 